\title{
Pembelajaran Daring Pada Mata Pelajaran Matematika Selama Pandemi Covid-19 di SMA Negeri 9 Mataram
}

\author{
Arthina Utami ${ }^{*}$, Sripatmi ${ }^{2}$, Syahrul Azmi ${ }^{2}$, Sri Subarinah ${ }^{2}$ \\ ${ }^{1}$ Mahasiswa Pendidikan Matematika, FKIP, Universitas Mataram, Mataram \\ 2 Pendidikan Matematika, FKIP, Universitas Mataram, Mataram \\ utamiarthina@gmail.com
}

Diterima: 16-12-2021 ; Direvisi: 30-12-2021; Dipublikasi: 30-12-2021

\begin{abstract}
This study aims to determine the order of the use of online learning platforms, the opinion of mathematical subjects teachers on the implementation of online learning, the obstacles encountered by mathematical subject teachers in using online learning platforms and the mathematics learning outcomes of students during online learning. The research method used is a mixed method. The subjects in this study were mathematics subject teachers, principal, vice principal in the curriculum field and students in class XI MIA 2 and XI MIA 4. The data collection techniques used were questionnaires, interviews and tests. The results showed that the easiest online learning platform to use to teach mathematics, monitor student activities and the most wasteful use of internet quota was the Zoom platform. The online learning platform that is easiest to use for evaluating mathematics subjects and the easiest to use for checking student learning outcomes is the Google Classroom platform. Mathematics subject teachers disagreed with the implementation of online learning. The obstacles encountered were difficulties in preparing, controlling and supervising students, making attractive learning models and media, using online learning platforms, teaching some materials, distinguishing students who took cooperation or independent work exams and learning facilities. students and internet networks. Meanwhile, the mathematics learning outcomes of students during online learning were not yet complete.
\end{abstract}

Keywords: learning platforms; online learning; mathematics learning outcomes

\begin{abstract}
Abstrak
Tujuan penelitian ini adalah untuk mengetahui urutan penggunaan platform pembelajaran daring yang digunakan oleh guru matematika, tanggapan guru matematika terhadap pelaksanaan pembelajaran daring, kendala yang ditemui oleh guru matematika dalam menggunakan platform pembelajaran daring serta hasil belajar matematika siswa. Jenis penelitian yang dilakukan adalah mixed methods. Subjek dalam penelitian ini adalah 9 guru mata pelajaran matematika, kepala sekolah, wakil kepala sekolah bidang kurikulum, dan siswa kelas XI MIA 2 dan kelas XI MIA 4. Teknik pengumpulan data yang digunakan adalah kuesioner, wawancara, dan tes. Hasil penelitian menunjukkan bahwa platform pembelajaran daring yang paling mudah digunakan untuk mengajarkan matematika, paling mudah digunakan untuk mengawasi aktifitas siswa dan yang paling boros penggunaan kuota internet adalah platform Zoom. Platform pembelajaran daring yang paling mudah digunakan untuk melakukan evaluasi kemampuan matematika dan yang paling mudah digunakan untuk memeriksa hasil belajar siswa adalah platform Google Classroom. Guru matematika tidak setuju terhadap pelaksanaan pembelajaran daring. Adapun kendala yang ditemui yaitu menyiapkan, mengontrol dan mengawasi siswa, membuat model dan media pembelajaran yang menarik, menggunakan platform pembelajaran daring, mengajarkan beberapa materi, membedakan siswa yang mengerjakan ujian kerjasama atau kerja mandiri serta sarana pembelajaran siswa dan jaringan internet. Sedangkan hasil belajar matematika siswa selama pembelajaran daring belum tuntas.
\end{abstract}

Kata Kunci: platforms pembelajaran; pembelajaran daring; hasil belajar matematika 


\section{PENDAHULUAN}

Pandemi Corona Virus Disease (Covid-19) adalah krisis kesehatan yang pertama dan terutama yang sedang terjadi di dunia. Penyebaran virus corona ini pada awalnya sangat berdampak pada dunia ekonomi yang mulai lesu, tetapi kini dampaknya dirasakan juga oleh dunia pendidikan. Banyak negara memutuskan untuk menutup sekolah, perguruan tinggi dan universitas. Perserikatan Bangsa-Bangsa (PBB) menjadi khawatir dengan adanya fakta tersebut. Organisasi Internasional yang bermarkas di New York, AS, itu menangkap bahwa pendidikan menjadi salah satu sektor yang begitu terdampak oleh virus corona. Parahnya lagi, hal itu terjadi dalam tempo yang cepat dan skala yang luas. Berdasarkan laporan ABC News 7 Maret 2020, penutupan sekolah terjadi di lebih dari puluhan negara. Menurut data Organisasi Pendidikan, Keilmuan, dan Kebudayaan PBB (UNESCO), setidaknya ada 290,5 juta peserta didik di seluruh dunia yang aktivitas belajarnya menjadi terganggu akibat sekolah yang ditutup.

Pandemi Corona Virus Disease (Covid-19) adalah krisis kesehatan yang pertama dan terutama yang sedang terjadi di dunia. Penyebaran virus corona ini pada awalnya sangat berdampak pada dunia ekonomi yang mulai lesu, tetapi kini dampaknya dirasakan juga oleh dunia pendidikan. Banyak negara memutuskan untuk menutup sekolah, perguruan tinggi dan universitas. Perserikatan Bangsa-Bangsa (PBB) menjadi khawatir dengan adanya fakta tersebut. Organisasi Internasional yang bermarkas di New York, AS, itu menangkap bahwa pendidikan menjadi salah satu sektor yang begitu terdampak oleh virus corona. Parahnya lagi, hal itu terjadi dalam tempo yang cepat dan skala yang luas. Berdasarkan laporan ABC News 7 Maret 2020, penutupan sekolah terjadi di lebih dari puluhan negara. Menurut data Organisasi Pendidikan, Keilmuan, dan Kebudayaan PBB (UNESCO), setidaknya ada 290,5 juta peserta didik di seluruh dunia yang aktivitas belajarnya menjadi terganggu akibat sekolah yang ditutup.

Berdasarkan Surat Edaran Kemendikbud Nomor 4 Tahun 2020 tentang pelaksanaan kebijakan pendidikan dalam masa darurat penyebaran Corona Virus Disease (Covid-19) yang menyatakan bahwa pembelajaran dilaksanakan dari rumah berupa pembelajaran dalam jaringan (daring) yang ditindaklanjuti oleh Walikota Mataram dengan Surat Edaran Nomor: 422.3/302/disdik.A/III/2020 yang menghimbau sekolah-sekolah di Kota Mataram untuk melakukan pembelajaran dalam jaringan (Daring), SMA Negeri 9 Mataram merupakan salah satu sekolah di Kota Mataram yang melaksanakan pembelajaran dalam jaringan (daring) tersebut. Berdasarkan hasil wawancara yang dilakukan oleh peneliti dengan salah satu guru matematika di SMA Negeri 9 Mataram, untuk memaksimalkan pelaksanaan pembelajaran dalam jaringan (Daring) di SMA Negeri 9 Mataram, sekolah melakukan banyak hal untuk memaksimalkan pelaksanaan pembelajaran daring tersebut. Diantaranya sekolah membagikan link-link seminar online mengenai pembelajaran inovatif di masa pandemi baik yang diadakan oleh KEMENDIKBUD maupun Dinas Pendidikan dan Kebudayaan Provinsi NTB dan organisasi lainnya. Sekolah juga turut mengadakan seminar online mengenai teknik pembuatan dan penggunaan beberapa platform pembelajaran daring seperti cara membuat google form, cara menggunakan Google Classroom, cara pembuatan video 
pembelajaran yang baik, dll sehingga guru dapat belajar melalui seminar-seminar tersebut. Sekolah juga mengadakan kerjasama dengan Quipper, yaitu sebuah aplikasi belajar online. Meskipun sekolah telah mengadakan kerjasama tersebut, sekolah tetap menyerahkan sepenuhnya kepada guru mengenai platform pembelajaran dalam jaringan (Daring) yang ingin digunakan. Sehingga selama proses pembelajaran dalam jaringan (Daring) di SMA Negeri 9 Mataram, platform yang digunakan oleh guru sangat bermacam-macam. Ada guru yang menggunakan grup whatsapp, Google Classroom dan juga mengunggah video pembelajaran di channel youtube pribadi kemudian peserta didik menonton video tersebut. Proses pelaksanaan pembelajaran melalui beberapa platform tersebut dilakukan dengan cara guru mengirim materi pembelajaran terlebih dahulu, kemudian peserta didik membaca atau menonton materi tersebut jika dalam bentuk video, selanjutnya peserta didik diberi waktu untuk menanyakan apa saja yang belum dimengerti dari materi yang telah diberikan. Video yang diberikan bisa berupa video materi pelajaran atau bisa juga video diri guru sedang menjelaskan materi. Selanjutnya setelah peserta didik paham mengenai materi pembelajaran, guru memberikan tugas jika diperlukan.

Berdasarkan uraian di atas, peneliti tertarik melakukan suatu penelitian untuk mengetahui urutan penggunaan platform pembelajaran daring yang digunakan oleh guru mata pelajaran matematika, pendapat guru mata pelajaran matematika terhadap pelaksanaan pembelajaran daring, kendala yang ditemui oleh guru mata pelajaran matematika dalam menggunakan platform pembelajaran daring serta hasil belajar matematika peserta didik selama pembelajaran daring di SMA Negeri 9 Mataram pada Tahun Ajaran 2020/2021 yang dikaji dalam penelitian berjudul "Pembelajaran Daring pada Mata Pelajaran Matematika Selama Pandemi Covid-19 di SMA Negeri 9 Mataram Tahun Ajaran 2020/2021".

\section{METODE PENELITIAN}

Jenis penelitian ini adalah penelitian kualitatif dengan pendekatan kualitatif desktiptif karena mendeskripsikan urutan penggunaan platform pembelajaran daring yang digunakan oleh guru mata pelajaran matematika, pendapat guru mata pelajaran matematika terhadap pelaksanaan pembelajaran daring, kendala yang ditemui oleh guru mata pelajaran matematika dalam menggunakan platform pembelajaran daring serta hasil belajar matematika peserta didik selama pembelajaran daring di SMA Negeri 9 Mataram pada Tahun Ajaran 2020/2021 (Moloeng, 2016). Penelitian ini dilakukan di SMA Negeri 9 Mataram pada tahun ajaran 2020/2021. Subjek dalam penelitian ini adalah guru mata pelajaran matematika SMA Negeri 9 Mataram yang berjumlah 5 orang, kepala SMA Negeri 9 Mataram, wakil kepala SMA Negeri 9 Mataram bidang kurikulum dan peserta didik kelas XI MIA 2 dan kelas XI MIA 4 SMA Negeri 9 Mataram.

Instrumen yang digunakan dalam penelitian ini adalah instrumen tes dan non tes. Insturmen non tes meliputi angket dan pedoman wawancara (Arikunto, 2013). Angket diberikan kepada guru mata pelajaran matematika SMA Negeri 9 Mataram untuk mengetahui urutan penggunaan platform pembelajaran daring yang digunakan oleh 
guru mata pelajaran matematika dan pendapat guru mata pelajaran matematika terhadap pelaksanaan pembelajaran daring di SMA Negeri 9 Mataram pada Tahun Ajaran 2020/2021. Pedoman wawancara diberikan kepada guru mata pelajaran matematika SMA Negeri 9 Mataram, kepala SMA Negeri 9 Mataram dan wakil kepala SMA Negeri 9 Mataram bidang kurikulum untuk mengetahui kendala yang ditemui oleh guru mata pelajaran matematika dalam menggunakan platform pembelajaran daring di SMA Negeri 9 Mataram pada Tahun Ajaran 2020/2021. Sedangkan instrumen tes berupa tes hasil belajar peserta didik tentang materi notasi sigma dan program linear yang diberikan kepada peserta didik kelas XI MIA 2 dan kelas XI MIA 4 SMA Negeri 9 Mataram untuk mengetahui hasil belajar matematika peserta didik pada ranah kognitif selama pembelajaran daring di SMA Negeri 9 Mataram pada Tahun Ajaran 2020/2021.

Hasil angket dan wawancara kemudian dianalisis menggunakan teknik analisis data deskriptif kualitatif. Hasil angket diberikan skor berdasarkan jawaban responden. Jawaban responden kemudian dihitung menggunakan rumus persentase. Persentase jawaban responden kemudian dikategorikan berdasarkan tabel kategori yang telah ditentukan. Hasil wawancara dianalisis melalui tahapan reduksi data, memilih mana yang penting dan yang akan dipelajari dan membuat kesimpulan (Hadi \& Haryono, 2015). Hasil tes peserta didik dianalisis melalui tahapan menentukan ketutasan individu berdasarkan KKM mata pelajaran matematika yang telah ditentukan yaitu 75 , kemudian menghitung rata-rata nilai kelas dan menghitung persentase ketuntasan belajar klasikal minimum $85 \%$.

\section{HASIL DAN PEMBAHASAN}

Pengambilan data dilakukan secara langsung dan tidak langsung. Pengambilan data secara langsung dilakukan dengan cara memberikan lembar angket kepada guru mata pelajaran matematika di SMA Negeri 9 Mataram dan pelaksanaan wawancara tatap muka dengan guru mata pelajaran matematika di SMA Negeri 9 Mataram, kepala SMA Negeri 9 Mataram dan wakil kepala SMA Negeri 9 Mataram dengan tetap mengikuti protokol kesehatan yang ditetapkan oleh sekolah. Pengambilan data secara tidak langsung dilakukan dengan cara memberikan soal tes hasil belajar kepada peserta didik secara daring yaitu melalui Google Classroom. Peneliti memberikan soal tes tersebut kepada guru mata pelajaran matematika kelas XI MIA 2 dan kelas XI MIA 4 kemudian guru tersebut mengupload soal di Google Classroom pada masing-masing kelas. Peserta didik diberikan waktu 60 menit untuk mengerjakan soal tes tersebut. Kemudian mengirimkan jawabannya pada Google Classroom masing-masing kelas. Peneliti kemudian ditambahkan oleh guru mata pelajaran matematika ke Google Classroom untuk mendownload jawaban tes hasil belajar peserta didik.

Berdasarkan hasil angket bagian A yang telah diisi oleh guru mata pelajaran matematika, diketahui bahwa rata-rata skor angket tanggapan guru mata pelajaran matematika terhadap pelaksanaan pembelajaran daring selama pandemi covid-19 di SMA Negeri 9 Mataram tahun ajaran 2020/2021 adalah sebesar 54.5\% dengan kategori tidak setuju. Sedangkan berdasarkan hasil angket bagian B yang telah diisi oleh guru 
mata pelajaran matematika, diketahui bahwa zoom merupakan platform pembelajaran daring yang paling mudah digunakan untuk mengajarkan mata pelajaran matematika, yang paling mudah digunakan untuk mengawasi aktifitas peserta didik pada mata pelajaran matematika dan yang paling boros penggunaan kuota internet. Sedangkan google classroom merupakan platform pembelajaran daring yang paling mudah digunakan untuk melakukan evaluasi (penilaian) pada mata pelajaran matematika dan yang paling mudah digunakan untuk memeriksa hasil belajar peserta didik.

Berdasarkan hasil wawancara yang dilakukan dengan guru mata pelajaran matematika di SMA Negeri 9 Mataram, kepala SMA Negeri 9 Mataram dan wakil kepala SMA Negeri 9 Mataram bidang kurikulum, kendala yang ditemui oleh guru mata pelajaran matematika dalam menggunakan platform pembelajaran daring di SMA Negeri 9 Mataram yaitu kesulitan menyiapkan, mengontrol dan mengawasi peserta didik, kesulitan membedakan peserta didik yang mengerjakan ujian kerjasama atau kerja mandiri, kesulitan membuat model dan media pembelajaran yang menarik, kesulitan menggunakan platform pembelajaran daring, kesulitan mengajarkan beberapa materi, serta kesulitan pada sarana pembelajaran peserta didik dan jaringan internet.

Berdasarkan hasil tes hasil belajar peserta didik yang diberikan kepada 71 orang peserta didik dari kelas XI MIA 2 dan kelas XI MIA 4, dapat dilihat bahwa hasil belajar peserta didik memiliki rata-rata nilai 74.5 dengan persentase ketuntasan belajar klasikal sebesar $78.2 \%$. Berdasarkan hasil tersebut, dari 23 orang peserta didik yang mengumpulkan jawaban tes dari kedua kelas terdapat 18 orang peserta didik yang nilainya mencapai KKM yaitu 75 (KKM mata pelajaran matematika wajib yang ditetapkan di SMA Negeri 9 Mataram) sedangkan 5 orang peserta didik nilainya belum mencapai KKM. Hasil tersebut belum mencapai ketuntasan belajar klasikal minimum sebesar 85\%.

\subsection{Urutan penggunaan platform pembelajaran daring yang digunakan oleh guru mata pelajaran matematika di SMA Negeri 9 Mataram pada Tahun Ajaran 2020/2021}

Platform pembelajaran daring yang digunakan oleh guru mata pelajaran matematika di SMA Negeri 9 Mataram yang pertama yaitu Google Classroom. Dari lima orang guru mata pelajaran matematika di SMA Negeri 9 Mataram, semuanya menggunakan platform Google Classroom untuk menyampaikan pelajaran. Fitur yang terdapat didalam Google Classroom sudah lengkap. Guru dapat membuat kelas kemudian membagikan tugas kepada kelas. Guru juga dapat menautkan beberapa platform lain seperti youtube, google form, dan lain-lain untuk proses penyampaian materi maupun proses evaluasi pembelajaran. Jawaban tugas yang dikirimkan oleh peserta didik hanya dapat dilihat oleh guru dan peserta didik yang mengirimkan jawaban sehingga dapat mengurangi masalah peserta didik yang mengikuti jawaban peserta didik yang lain. Platform pembelajaran daring yang digunakan oleh guru mata pelajaran matematika di SMA Negeri 9 Mataram yang kedua yaitu WhatsApp Group. Hanya satu orang guru mata pelajaran matematika yang mengajar daring menggunakan platform WhatsApp Group. 
Guru membuat WhatsApp Group sehingga seluruh siswa dapat terlibat dalam group. Tugas-tugas diberikan melalui WhatsApps group yang biasanya juga ditautkan dengan google form. Jika siswa masih belum memahami maka guru juga akan menambahkan dengan mengirimkan video pembelajaran.

Selanjutnya siswa mengunduh materi dan mempelajari materi dari guru. Alasan guru lebih memilih menggunakan WhatsApp Group adalah karena lebih praktis, lebih mudah dipahami anak, lebih efektif kerena tidak membutuhkan banyak kuota internet dalam penggunaannya sehingga tingkat partisipasi peserta didik juga lebih tinggi. Hal ini sesuai dengan teori yang diungkapkan oleh Gusty et al. (Gusti et al., 2020: 51-52) bahwa whatsapp digunakan oleh semua kalangan karena penggunaannya yang mudah dan tidak membutuhkan kuota internet yang besar. Platform pembelajaran daring yang digunakan oleh guru mata pelajaran matematika di SMA negeri 9 Mataram yang ketiga yaitu Zoom. Platform Zoom digunakan oleh tiga orang guru mata pelajaran matematika di SMA Negeri 9 Mataram. Pembelajaran daring menggunakan platform Zoom lebih menarik karena komunikasi dapat berlangsung secara dua arah sehingga guru dapat menerima respon siswa secara cepat. Pembelajaran daring melalui platform Zoom membuat guru dapat bertatap muka dengan peserta didik walaupun secara virtual. Guru menjadi lebih mudah menjelaskan materi pelajaran.

Selain ketiga platform yang telah dijelaskan, guru mata pelajaran matematika di SMA Negeri 9 Mataram juga pernah menggunakan platform Ruang Guru dan Quipper, tetapi tidak dapat berjalan sebagaimana yang diinginkan karena banya siswa yang tidak mengerti cara penggunaan platformnya, banyak siswa yang mengeluhkan tidak dapat menginstal platform tersebut di smartphone mereka dan masalah akses internet. Dari ketiga platform pembelajaran daring tersebut, Zoom merupakan platform pembelajaran daring yang paling mudah digunakan untuk mengajar, yang paling mudah digunakan untuk mengawasi peserta didik pada mata pelajaran matematika dan yang paling boros penggunaan kuota internet. Hal ini sesuai dengan teori yang diungkapkan oleh Gusty et al. (Gusti et al., 2020: 53) bahwa Zoom merupakan platform pembelajaran daring yang membutuhkan paket data lebih besar.

Sedangkan google classroom merupakan platform pembelajaran daring yang paling mudah digunakan untuk melakukan evaluasi dan memeriksa hasil evaluasi pembelajaran pada mata pelajaran matematika. Hal ini sesuai dengan teori yang diungkapkan oleh Nurani et al. (Nurani et al., 2020) bahwa google classroom merupakan sebuah platform pembelajaran daring yang memudahkan guru untuk melakukan evaluasi setiap kegiatan pembelajaran yang dilakukan oleh peserta didik.

\subsection{Pendapat guru mata pelajaran matematika terhadap pelaksanaan pembelajaran daring di SMA Negeri 9 Mataram pada Tahun Ajaran 2020/2021}

Berdasarkan hasil analisis data deskriptif kualitatif dari angket pendapat guru mata pelajaran matematika terhadap pelaksanaan pembelajaran daring yang diisi oleh lima 
orang guru mata pelajaran matematika di SMA Negeri 9 Mataram, guru tidak setuju dengan pelaksanaan pembelajaran daring dilihat dari rata-rata perolehan skor pada angket sebesar $54.5 \%$ dengan kategori tidak setuju. Hal ini dikarenakan dalam pelaksanaan pembelajaran daring guru menemukan beberapa kendala baik kendala pada proses pembelajaran maupun kendala pada sarana pembelajaran. Pada tahap persiapan pembelajaran daring, guru kesulitan menggunakan platform pembelajaran daring. Pada proses pembelajaran guru kesulitan menyiapkan, mengontrol dan mengawasi peserta didik. Guru juga kesulitan menerapkan model dan media pembelajaran yang menarik.

Selain itu, pada pelaksanaan pembelajaran daring juga terkendala pada sarana pembelajaran yang dimiliki peserta didik, seperti hp, laptop dan jaringan internet. Hal ini sejalan dengan penelitian yang dilakukan oleh Nabila \& Sulistiyaningsih (Nabila \& Sulistiyaningsih, 2020) yang menyatakan bahwa kendala yang paling sering dialami siswa adalah kendala teknis yang berkaitan dengan signal yang dapat mengakibatkan siswa kurang maksimal dalam proses pembelajaran daring. Selain itu, peserta didik juga tidak mahir menggunakan internet, tidak mempunyai hp sendiri, serta menganggap aplikasi yang digunakan sebagai media pembelajaran daring tidak cocok untuk pembelajaran matematika. Agar pembelajaran daring lebih efektif, guru menyarankan agar sekolah lebih memperhatikan sarana dan prasarana yang dimiliki oleh peserta didik maupun guru.

\subsection{Kendala yang ditemui oleh guru mata pelajaran matematika dalam menggunakan platform pembelajaran daring di SMA Negeri 9 Mataram pada Tahun Ajaran 2020/2021}

Kendala adalah permasalahan yang mengganggu dan menghambat atau mempersulit suatu proses. Kendala dalam proses pembelajaran adalah permasalahan yang menghambat pencapaian tujuan pembelajaran dan menghambat jalannya pembelajaran. Begitu juga dalam pembelajaran daring di SMA Negeri 9 Mataram. Sebagai pengganti pembelajaran tatap muka yang menuntut guru mata pelajaran matematika harus memilih platform yang tepat untuk pelaksanaan pembelajaran daring, dalam penggunaannya pasti tidaklah sempurna pasti terdapat kendala atau kesulitan. Proses pembelajaran daring sebagai akibat dari pandemic covid-19 di SMA Negeri 9 Mataram belum berjalan dengan baik karena terdapat beberapa masalah dalam pelaksanannya.

Kendala yang pertama yaitu guru kesulitan menyiapkan, mengontrol dan mengawasi peserta didik baik pada tahap persiapan, pelaksanaan pembelajaran maupun pada tahap evaluasi pembelajaran. Hal ini dirasakan oleh hamper semua guru mata pelajaran matematika yang menggunakan platform Google Classroom dan WhatsApp Group. Kendala dalam mengawasi peserta didik pada tahap evaluasi pembelajaran menyebabkan kendala lainnya, yaitu guru menjadi kesulitan membedakan apakah tugas yang dikerjakan oleh peserta didik merupakan hasil kerja mandiri peserta didik atau mengikuti jawaban temannya. Hal ini menyebabkan guru kesulitan membedakan 
apakah siswa sudah paham atau belum dengan materi yang diajarkan karena guru hanya bisa menilai melalui jawaban tugas yang dikirimkan, tidak dapat menilai pelaksanaan pengerjaan tugas. Beberapa guru mengatasi hal tersebut dengan cara meminta peserta didik untuk membuat video diri sedang menjelaskan jawaban tugas yang mereka kumpulkan.

Kendala selanjutnya yaitu guru kesulitan menyampaikan beberapa materi pelajaran misalnya materi program linear karena memuat cara menggambar grafik. Hal ini dirasakan oleh guru mata pelajaran matematika yang menggunakan platform Google Classroom. Kesulitan ini dikarenakan pada Google Classroom hanya bisa komunikasi via text sehingga respon peserta didik sedikit lambat. Jika hanya dituliskan cara menggambar grafik, dikhawatirkan peserta didik tidak memahami tata cara tersebut sehingga perlu dipraktekan secara langsung. Guru mata pelajaran matematika mengatasi hal ini dengan cara mengganti platform pembelajaran menggunakan Google Classroom dengan Zoom.

Kendala yang keempat yaitu sarana dan akses internet siswa maupun guru yang tidak selalu lancar. Hal ini dirasakan pada penggunaan platform Google Classroom dan Zoom. Untuk platform Zoom, penggunaannya memang membutuhkan signal yang bagus dan kuota internet yang lumayan banyak sehingga pada pembelajaran daring menggunakan Zoom partisipannya lebih sedikit. Untuk mengatasi kendala akses internet ini, guru terkadang meminta peserta didik yang terkendala pada akses internet untuk datang ke sekolah dan menggunakan fasilitas yang ada di sekolah yaitu jaringan internet berupa wifi.

Kendala yang kelima yaitu guru kesulitan menciptakan model dan media pembelajaran yang menarik. Hal ini dirasakan pada penggunaan platform WhatsApp Group. Kendala ini terjadi karena pembelajaran daring melalui WhatsApp Group hanya menggunakan satu metode sehingga pembelajaran terkesan membosankan. Guru kesulitan menerapkan model pembelajaran. Setiap hari pembelajaran dilaksanakan dengan cara mengirimkan materi berupa text, jika peserta didik belum mengerti kemudian guru mengirimkan video pembelajaran. Kendala yang terakhir yaitu, ada guru yang tidak bisa menggunakan platform pembelajaran daring pada saat pertama kali diterapkan pembelajaran daring, guru tersebut mengatasi hal ini dengan cari mengikuti pelatihanpelatihan mengenai platform pembelajaran daring yang diadakan oleh sekolah serta mempelajari platform-platfom pembelajaran daring melalui internet secara mandiri.

\subsection{Hasil belajar matematika peserta didik selama pembelajaran daring di SMA Negeri 9 Mataram pada Tahun Ajaran 2020/2021}

Tes hasil belajar peserta didik diberikan kepada 71 orang peserta didik kelas XI MIA 2 dan kelas XI MIA 4. Tes dikerjakan selama 60 menit. Setelah 60 menit, peserta didik yang mengumpulkan jawaban hanya 23 orang peserta didik dari kedua kelas tersebut, 48 orang peserta didik lainnya sudah diingatkan oleh guru mata pelajaran matematika untuk segera mengumpulkan jawaban tes. Akan tetapi, setelah diberikan perpanjangan 
waktu, 48 orang peserta didik tersebut tetap tidak mengumpulkan jawaban tes. Hal ini disebabkan karena kurangnya perhatian peserta didik terhadap pembelajaran.

Berdasarkan analisis hasil belajar peserta didik, dari 23 orang peserta didik yang mengumpulkan jawaban, hanya 18 orang peserta didik yang nilainya mencapai KKM yaitu 75 sesuai dengan KKM mata pelajaran matematika yang telah ditentukan oleh sekolah. Adapun persentase ketuntasan belajar klasikal yang dicapai sebesar $78.2 \%$. Ketuntasan belajar klasikal ini belum mencapai minimum sebesar 85\%. Hal ini dikarenakan masih banyak kekurangan-kekurangan pada proses pembelajaran. Berdasarkan hasil wawancara dengan peserta didik yang nilainya belum mencapai KKM, dalam mengerjakan soal tes hasil belajar tersebut peserta didik mengalami kesulitan.

Beberapa kesulitan yang dialami yaitu peserta didik kesulitan menggunakan platform yang digunakan larena tidak memadai di hp peserta didik. Platform google classroom yang digunakan sering eror dan terkadang soal yang dikirimkan tidak dapat ditampilkan. Peserta didik juga mengalami kesulitan dalam mengerjakan soal karena kurang paham dengan materi yang diajarkan. Dalam pelaksanaan pembelajaran daring, tidak semua platform pembelajaran daring memberi kemudahan kepada guru untuk menyampaikan materi. Ada guru yang merasa kesulitan dalam menyampaikan beberapa materi jika menggunakan Google Classroom seperti materi pelajaran yang mengharuskan guru untuk menggambar grafik. Jika hanya diberikan grafik yang sudah jadi dan langkah-langkah menggambarnya dikhawatirkan peserta didik kurang paham, sehingga dibutuhkan platform pembelajaran daring yang memberikan fitur tatap muka seperti Zoom. Akan tetapi, pembelajaran daring menggunakan platform Zoom tidak selalu lancar. Hal ini dikarenakan penggunaan kuota internet menggunakan platform Zoom lebih banyak dibandingkan platform yang lain. Sehingga tidak semua peserta didik dapat menjangkau platform tersebut yang berakibat pada rendahnya aktivitas dan keikutsertaan peserta didik dalam proses pembelajaran.

\section{SIMPULAN}

Berdasarkan hasil analisis dan pembahasan tentang pembelajaran daring pada mata pelajaran matematika selama pandemic covid-19 di SMAN Negeri 9 Mataram, maka terdapat beberapa hal yang menjadi garis besar sebagai kesimpulan sebagai berikut:

a. Platform pembelajaran daring yang digunakan oleh guru mata pelajaran matematika di SMA Negeri 9 Mataram ada tiga platform yaitu Google Classroom, WhatsApp Group dan Zoom. Semua guru mata pelajaran matematika menggunakan platform Google Classroom selama pembelajaran daring, tiga orang guru mata pelajaran matematika menggunakan platform Zoom selama pembelajaran daring dan hanya satu orang guru mata pelajaran matematika menggunakan platform WhatsApp Group selama pembelajaran daring. Platform pembelajaran daring yang paling mudah digunakan untuk mengajarkan mata pelajaran matematika, paling mudah digunakan untuk mengawasi aktifitas peserta didik dan yang paling boros penggunaan kuota internet adalah platform Zoom. Platform pembelajaran daring yang paling mudah digunakan 
untuk melakukan evaluasi pada mata pelajaran matematika dan yang paling mudah digunakan untuk memeriksa hasil belajar peserta didik adalah platform Google Classroom.

b. Guru mata pelajaran matematika tidak setuju terhadap pelaksanaan pembelajaran daring di SMA Negeri 9 Mataram.

c. Kendala yang ditemui oleh guru mata pelajaran matematika dalam menggunakan platform pembelajaran daring di SMA Negeri 9 Mataram yaitu kesulitan menyiapkan, mengontrol dan mengawasi peserta didik, kesulitan membuat model dan media pembelajaran yang menarik, kesulitan menggunakan platform pembelajaran daring, kesulitan mengajarkan beberapa materi, kesulitan membedakan peserta didik yang mengerjakan ujian kerjasama atau kerja mandiri serta kesulitan pada sarana pembelajaran peserta didik dan jaringan internet.

d. Hasil belajar matematika peserta didik selama pembelajaran daring di SMA Negeri 9 Mataram belum tuntas ditinjau dari persentase ketuntasan klasikal. Persentase ketuntasan belajar klasikal yang dicapai hanya $78.2 \%$, kurang dari minimum $85 \%$. Dari 23 orang peserta didik yang mengumpulkan jawaban tes, hanya 18 orang peserta didik yang nilainya mencapai KKM yang telah ditentukan yaitu 75 . Bagian ini memaparkan simpulan penelitian sesuai dengan hasil dan temuan penelitian. Bagian ini tidak perlu ada kutipan atas simpulan. Kesimpulan menggambarkan jawaban atas hipotesis dan / atau tujuan penelitian atau temuan ilmiah yang diperoleh. Kesimpulan tidak mengandung pengulangan hasil dan diskusi, melainkan merangkum temuan seperti yang diharapkan dalam tujuan atau hipotesis.

\section{UCAPAN TERIMA KASIH}

Penulis mengucapkan terima kasih yang sebesar-besarnya kepada Program Studi Pendidikan Matematika FKIP Universitas Mataram dan seluruh warga SMA Negeri 9 Mataram yang sudah membantu selama penelitian berlangsung.

\section{REFERENSI}

Arikunto, S. (2013). Dasar-dasar evaluasi pendidikan. Jakarta: PT. Bumi Aksara.

Gusti, S., Nurmiati, Muliana, Sulaiman, O. K., Ginantra, N. L. W. S. R., ... Sudarso, A. (2020). Belajar mandiri: pembelajaran daring di tengah pandemi covid-19. Medan: Yayasan Kita Menulis.

Hadi, A., \& Haryono. (2015). Metodologi penelitian pendidikan. Bandung: CV. Pustaka Setia.

Moleong, L. J. (2016). Metodologi penelitian kualitatif. Bandung: PT. Remaja Rosdakarya

Nabila, H., \& Sulistiyaningsih, D. (2020). Analisis kesulitan belajar matematika dalam pembelajaran daring berbantuan microsoft teams kelas XI SMA Negeri 9 Semarang. Prosiding Seminar Edusainstech FMIPA UNIMUS, $\quad 4(1)$ : 62-71. https://prosiding.unimus.ac.id/index.php/edusaintek/article/view/544

Nurani, N. I., Uzwatun, D. A., \& Maula, L. H. (2020). Analisis proses pembelajaran matematika Berbasis Daring Menggunakan aplikasi google classroom pada masa pandemi covid-19. Jurnal PGSD, 6(1): 50-56. https://doi.org/10.32534/jps.v6i1.1151 